\title{
Prevalence and Pattern of Hypodontia among Croatian Orthodontic Patients
}

\section{Učestalost i obrazac hipodoncije kod ortodontskih pacijenata u Hrvatskoj}

\author{
${ }^{1}$ Postgraduate student, School of Dental Medicine, University of Zagreb, Croatia \\ Diplomantica na poslijediplomskom studiju Stomatološkog fakulteta Sveučilišta u Zagrebu, Hrvatska \\ 2 Dental Polyclinic Zagreb, Croatia \\ Stomatološka poliklinika Zagreb, Hrvatska \\ ${ }^{3}$ Dental Center Kranjčević Bubica, Zadar, Croatia \\ Dentalni centar Kranjčević Bubica, Zadar, Hrvatska \\ ${ }^{4}$ Department of Orthodontics, School of Dental Medicine, University of Zagreb, Croatia \\ Zavod za ortodonciju Stomatološkog fakulteta Sveučilišta u Zagrebu, Hrvatska
}

\section{Abstract}

Objective: The objective of this retrospective study was to assess the prevalence of hypodontia in the permanent dentition among Croatian orthodontic patients. The occurrence was evaluated concerning gender, specific missing teeth, the location, pattern of distribution in the maxillary and mandibular arches and sagittal and vertical skeletal pattern. Material and Methods: The sample consisted of 194 patients ( 75 males and 119 females) from the Department of Orthodontics, Dental Clinic, Clinical Hospital Center Zagreb. Based on the severity of hypodontia the sample was divided into mild (1-2 missing teeth), moderate (3-5 missing teeth) and severe groups (6 or more missing teeth). The location of missing teeth was used to further divide the sample into anterior (intercanine region), posterior (premolars and molars) and anteroposterior groups. In addition, jaw localization of hypodontia was also considered. Results: Permanent dentition hypodontia among Croatian orthodontic patients was found to be generally mild ( $80 \%)$, and a distribution was similar in the maxilla (39\%) and the mandible ( $41 \%)$, as well as in the anterior and posterior segments of dental arch (44\%). The number of missing teeth per person ranged from 1 to 12 , with no significant difference between genders. The severity and location of hypodontia did not differ significantly between the genders, as well as in between the categories of sagittal and vertical skeletal patterns. Conclusion: Present results suggest that the treatment plan for patients with hypodontia in permanent dentition should be individualized and adjusted for each case.
Received: March 13, 2020

Accepted: June 1, 2020

Address for correspondence Daša Nikolov Boric

Health Care Center Zagreb

Runjaninova 4, Zagreb

nikolov_dasha@hotmail.com

Key words

Anodontia; Permanent Dentition; Rotation Pattern; Croatia

\section{Introduction}

Hypodontia is a congenital absence of one or more permanent teeth, excluding third molars (1). It represents the most common developmental anomaly of the human dentition (2). The prevalence of hypodontia in permanent dentition varies among different ethnic groups, by gender and geographical location, and ranges from $1.6 \%$ to $36.5 \%$ (3). The prevalence of hypodontia in Europe is $4.6 \%$ for males and $6.3 \%$ for females, while in Australia it is $5.5 \%$ for males and $7.6 \%$ for females (4). In North America, the prevalence among the Caucasians is lower than in Europe and Australia, with 3.2\% for males and $4.6 \%$ for females (4). Regarding the gender, hypodontia affects women more often than men, precisely 1.37 times more (4). The teeth most affected with hypodontia are as follows: lower second premolar, upper lateral incisor and upper second premolar. Bilateral hypodontia is more common only when the upper lateral incisor is missing,
Uvod

Hipodoncija je kongenitalni nedostatak jednoga ili više zuba, isključujući umnjake (1). Jedna je od najčešćih anomalija u razvoju ljudske denticije (2). Učestalost hipodoncije u trajnoj denticiji varira među različitim etničkim skupinama, prema spolovima i zemljopisnim položajima, te se kreće u rasponu od 1,6\% do 36,5\% (3). Prevalencija hipodoncije u Europi iznosi 4,6 \% za muški i 6,3 \% za ženski spol, a u Australiji 5,5 \% iznosi za muškarce i 7,6 \% za žene (4). U Sjevernoj Americi među pripadnicima bijele rase učestalost je manja u odnosu prema Europi i Australiji te iznosi 3,2 \% za muški i 4,6 \% za ženski spol (4). S obzirom na spol hipodoncija češće pogađa žene, točnije 1,37 puta više negoli muškarce (4). Zubi koji najčešće nedostaju jesu redom: donji drugi pretkutnjak, gornji lateralni sjekutić i gornji drugi pretkutnjak. Obostrana hipodoncija češća je samo u slučaju nedostatka gornjega lateralnog sjekutića, a u slučajevima nedostat- 
whereas in cases where other types of teeth are missing, unilateral hypodontia is more common (4). The absence of one or two teeth is present in $83 \%$ of subjects with hypodontia (4). There is no statistically significant difference between the prevalence of hypodontia in the maxilla and mandible (4).

The aim of this retrospective study was to assess the prevalence of hypodontia in the permanent dentition among Croatian orthodontic patients. The occurrence was evaluated concerning gender, specific missing teeth, the location and pattern of distribution in the maxillary and mandibular arches and in the sagittal and vertical skeletal pattern.

\section{Material and Methods}

The sample was gained from the patients' database of the Department of Orthodontics, Dental Clinic, Clinical Hospital Center Zagreb. It consisted of 194 subjects $(75$ males and 119 females) between the ages of 10 and 18 . After clinical examination, hypodontia was further confimed by analyzing patients' radiographic images.

Based on the severity of hypodontia, the sample was divided into mild (1-2 missing teeth), moderate (3-5 missing teeth) and severe groups (6 or more missing teeth). The location of missing teeth was used to further divide the sample into anterior (intercanine region), posterior (premolars and molars) and anteroposterior groups. Also, it was considered which jaw was affected.

The inclusion criteria for this study were permanent dentition hypodontia and Croatian ethnicity, while exclusion criteria were craniofacial syndromes, cleft lip and/or palate, history of teeth trauma and previous orthodontic treatment.

A customized cephalometric analysis was performed by DOLPHIN IMAGE software (v.11.5) on lateral cephalograms that were taken as a part of a standard procedure prior to treatment. To determine the sagittal relationships, ANB angle was observed. The values of $2.5 \pm 2$ were defined as a skeletal Class I, $>4.5$ as Class II and $<0.5$ as Class III. Vertical relationships were estimated using the Jarabak's ratio of posterior and anterior facial height (S-Go : N-Me), with a standard value of $65.5 \% \pm 3.5 \%$. The subjects with a ratio of less than $62 \%$ were classified as having a vertical growth pattern and and those with a ratio of more than $69 \%$ were classified as having a horizontal growth pattern.

The Chi square test with Cramer V for effect size were used for comparison of categories. The Mann-Whitney test for comparison of number of teeth between sexes was applied, while the Rosenthal formula $\mathrm{r}=\mathrm{Z} / \sqrt{\mathrm{N}}$ was used to calculate the effect size. Data were analysed in SPSS 16.0 software (SPSS Inc., Chicago, USA).

The Ethics Committee of the Zagreb School of Dental Medicine approved this study. An informed consent forms authorizing the use of patients radiograms were signed by each patient or their parent, if they were under 18 . ka drugih zuba češća je jednostrana hipodoncija (4). Kod 83 $\%$ ispitanika s hipodoncijom nedostaju jedan do dva zuba (4). Učestalost hipodoncije u maksili u usporedbi s mandibulom bez značajnih je razlika (4).

Svrha ovoga retrospektivnog istraživanja bila je procijeniti učestalost hipodoncije u trajnoj denticiji u populaciji ortodontskih pacijenata u Republici Hrvatskoj. Pojavnost je procijenjena s obzirom na spol, specifične zube koji nedostaju, lokalizaciju po čeljustima i prema segmentima čeljusti, te s obzirom na sagitalne i vertikalne skeletne obrasce rasta.

\section{Ispitanici i postupci}

Uzorak je izdvojen iz baze podataka pacijenata Zavoda za ortodonciju Klinike za stomatologiju Kliničkoga bolničkog centra Zagreb. Sastojao se od 194 ispitanika (75 muškoga i 119 ženskoga spola), u dobi od 10 do 18 godina. Nakon kliničkoga pregleda, hipodoncija je potvrđena analizom rendgenskih snimki pacijenata.

Prema opsežnosti hipodoncije ispitanici su podijeljeni u skupine s blagom (nedostatak 1-2 zuba), umjerenom (nedostatak $3-5$ zuba) te ozbiljnom hipodoncijom (nedostatak 6 ili više zuba). Prema lokalizaciji hipodoncije u segmentima čeljusti, ispitanici su podijeljeni u skupine s anteriornom (interkanina regija), posteriornom (regija premolara i molara) te antero-posteriornom hipodoncijom (kombinacija prvih dviju skupina). U obzir je također uzeta lokalizacija hipodoncije po čeljustima.

Uključujući kriteriji za izbor ispitanika bili su hipodoncija u trajnoj denticiji te hrvatska populacija, a isključujući kriteriji bili su kraniofacijalni sindromi, rascjep usne i/ili nepca, prijašnja trauma zuba i prijašnja ortodontska terapija.

Na laterolateralnim kraniogramima, snimljenima kao dio standardnog postupka prije početka ortodontske terapije, za svakoga ispitanika učinjena je kefalometrijska analiza s pomoću programske podrške DOLPHIN IMAGE (v. 11.5). $\mathrm{Za}$ određivanje sagitalnih međučeljusnih odnosa korišten je ANB kut. Vrijednosti od $2,5^{\circ} \pm 2$ definirane su kao skeletna klasa I, one veće od $4,5^{\circ}$ kao klasa II, te manje od $0,5^{\circ}$ kao klasa III. Vertikalni međučeljusni odnosi procijenjeni su s pomoću Jarabakova omjera stražnje i prednje visine lica (S-Go : N-Me), standardne vrijednosti $65,5 \% \pm 3,5 \%$. Ispitanici s omjerom manjim od $62 \%$ svrstani su u kategoriju vertikalnog obrasca rasta, a oni s omjerom većim od $69 \%$ uvršteni su u kategoriju horizontalnog obrasca rasta.

Statistička analiza učinjena je u komercijalnom programu SPSS 16.0 (SPSS Inc., Chicago, SAD). Za usporedbu kategorijalnih varijabli korišsten je $\chi^{2}$-test, a za procjenu snage efekta Cramerov V. Za usporedbu broja zuba među spolovima korišsten je Mann-Whitneyjev test, a snaga efekta izračunata je Rosenthalovom formulom $r=Z / \sqrt{N}$.

Istraživanje je odobrilo Etičko povjerenstvo Stomatološkoga fakulteta Sveučilišta u Zagrebu. Svaki pacijent, odnosno roditelj u slučaju maloljetnosti pacijenta, potpisao je informirani pristanak kojim se odobrava uporaba pacijentovih RTG-snimki. 


\section{Results}

Females $(61.3 \%)$ were more affected with hypodontia than males $(38.7 \%)$.

The number of missing teeth per person ranged from 1 to 12 (median 2, interquartile range 1-2) and did not differ between the genders ( $\mathrm{p}=0.590$; Figure 1$)$.

Hypodontia was found to be generally mild (80\%), localized equally in the maxilla (39\%) and the mandible (41\%) and in both the anterior and posterior segments of dental $\operatorname{arch}(44 \%)$.

The severity and location of hypodontia did not differ significantly between the genders ( $\mathrm{p} \geq 0.106$; Figures 2-4).

The severity and location of hypodontia also did not differ between the categories of facial rotation patterns or between skeletal classes ( $\mathrm{p} \geq 0.105$; Figures 5-10) in a statistically significant manner.

\section{Discussion}

The differences between studies about hypodontia, regarding sampling, age range and gender, make their comparison difficult (2). For defining the incidence and distribution of hypodontia in the human population, meta-analyses have a great importance and majority of the authors are referring to them. The best examples are studies published by Polder et al. in 2004. (4) and by Khalaf et al. in 2014. (2). The latter reported of a higher prevalence of hypodontia than stated before, which might be a result of using better diagnostics and having a greater number of prevalence studies.

In the present study, hypodontia was found to be generally mild (80\%), meaning that most of the subjects were missing one or two teeth. Similar findings were reported in some other studies (5-7).

The severity and location of hypodontia did not differ significantly between the genders, which was also found in previous studies $(7,10,13,17,32,33)$. When it comes to number of missing teeth and sexual dysmorphism, there is much more evidence that females are at greater risk of being affected with more severe hypodontia than males $(13,14,16,34-37)$.

The results as which arch is predominantly affected with hypodontia are not conclusive (8). According to some authors, there seems to be no significant difference between the prevalence of hypodontia in the maxilla and mandible $(4,5$, 9, 30), which was also confirmed in our study. Many previous studies concluded that the maxilla was more frequently affected with hypodontia than mandible $(6,7,10-14,31)$. There is also a group of authors who had found a greater rate in the mandible (15-21).

Few studies have evaluated the distribution of hypodontia in the anterior and posterior segments of dental arch (10, $13,22)$. Some authors reported that the anterior segment is more affected with hypodontia $(10,13,23)$, while others noted that the posterior tooth agenesis increased with hypodontia severity $(5,22)$. Our findings suggest that hypodontia is equally localized in the anterior and posterior segments of dental arch.

No statistically significant difference was found between the categories of facial rotation patterns or between skeletal

\section{Rezultati}

Hipodoncija je bila zastupljenija u ispitanica $(61,3 \%) \mathrm{u}$ odnosu prema ispitanicima $(38,7 \%)$.

Broj zuba koji nedostaju kretao se u rasponu od 1 do 12 po osobi (medijan 2, interkvartilni raspon $1-2$ ) i nije se razlikovao među spolovima ( $p=0,590$; slika 1.). Hipodoncija je uglavnom bila blaga (80\%), podjednako zastupljena u maksili (39\%) i mandibuli (41\%), te u prednjim i stražnjim segmentima čeljusti (44\%).

Opsežnost i lokalizacija hipodoncije nisu se značajno razlikovale među spolovima ( $\mathrm{p} \geq 0,106$; slike 2-4).

Opsežnost i lokalizacija hipodoncije također se nisu statistički značajno razlikovale između kategorija obrazaca rotacijskog rasta lica, ni između skeletnih klasa ( $\mathrm{p} \geq 0,105$; slike $5-10)$.

\section{Rasprava}

Različitosti između studija srodne tematike, s obzirom na uzorkovanje, raspon dobi i zastupljenost prema spolovima, otežavaju njihovu usporedbu (2). Velik doprinos za utvrđivanje učestalosti i raspodijeljenosti hipodoncije u ljudskoj populaciji možemo zahvaliti metaanalizama na koje se referira većina autora. Najbolji primjeri su studije koje su objavili Polder i suradnici 2004. (4) te Khalaf i suradnici 2014. godine (2). U ovoj posljednjoj autori iznose zaključak o većoj učestalosti hipodoncije nego što se to prije tvrdilo, što bi moglo biti rezultat korištenja kvalitetnijih dijagnostičkih metoda, te većeg broja dostupnih studija o toj temi.

U ovom istraživanju hipodoncija je bila uglavnom blaga (80\%), što znači da su većini ispitanika nedostajali jedan do dva zuba. Jednako zaključuju i istraživači u još nekim studijama $(5-7)$.

Opsežnost i lokalizacija nisu se značajno razlikovale među spolovima, kako je utvrđeno i prije $(7,10,13,17,32$, 33). Za korelaciju između broja zuba zahvaćenih hipodoncijom i spola, u literaturi se pronalazi mnogo više dokaza da su žene sklonije ozbiljnoj hipodonciji od muškaraca $(13,14$, 16, $34-37$ ).

Rezultati studija vezani uz predominaciju čeljusti zahvaćene hipodoncijom nisu konzistentni (8). Prema nekim autorima, čini se da ne postoji statistički značajna razlika u učestalosti hipodoncije u čeljustima $(4,5,9,30)$, a to je potvrđeno i u ovom istraživanju. U mnogo dosadašnjih studija istraživači zaključuju da je maksila češće zahvaćena hipodoncijom od mandibule $(6,7,10-14,31)$. No, postoji skupina autora koji su pronašli veću stopu hipodoncije u mandibuli $(15-21)$.

Samo u nekoliko studija autori su proučavali raspodijeljenost hipodoncije u prednjim i stražnjim segmentima zubnih lukova $(10,13,22)$. U nekima je utvrđena veća učestalost u prednjem segmentu $(10,13,23)$, a u drugima je uočeno da zahvaćenost stražnjeg segmenta raste s povećanjem broja zuba koji nedostaju $(5,22)$. Ovo istraživanje je pokazalo da je hipodoncija jednako zastupljena u oba segmenta.

Nije pronađena statistički značajna razlika između kategorija obrazaca rotacijskog rasta lica, ni između skeletnih klasa s obzirom na opsežnost i lokalizaciju hipodoncije. Ozbiljna 
classes regarding the severity and location of hypodontia. Severe hypodontia, according to some studies, was associated with Class III malocclusion $(24,25)$. Hirukawa et al. (26) reported that hypodontia in the maxilla was commonly associated with Class III, while Class II was more common among subjects with hypodontia in the mandible.

It is assumed, that an anterior rotation of the mandible is attributed to a lack in occlusal support, arising from a large hipodoncija je u nekim studijama povezana s malokluzijama klase III $(24,25)$. Hirukawa i suradnici (26) uočili su povezanost hipodoncije u maksili s klasom III, a klasa II bila je češća kod ispitanika s hipodoncijom u mandibuli.

Pretpostavlja se da se prednja rotacija mandibule pripisuje nedostatku okluzalne potpore koja proizlazi iz nedostatka velikog broja zuba (27). O sklonosti horizontalnom obrascu rasta kod ispitanika s posteriornom hipodoncijom izvijestili

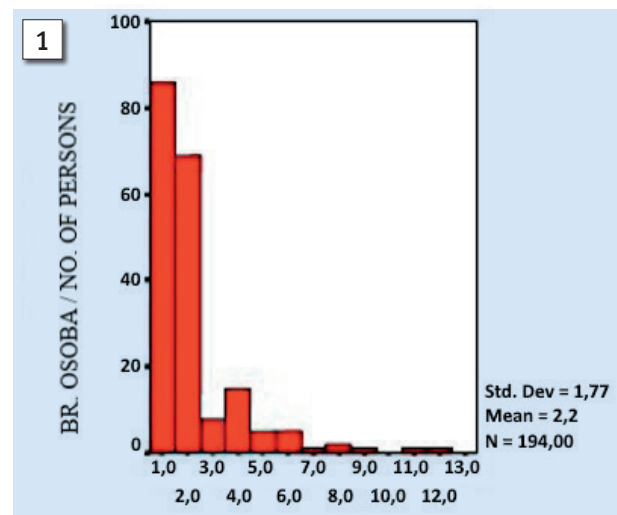

BR. ZUBI KOJI NEDOSTAJU / NO. OF MISSING TEETH
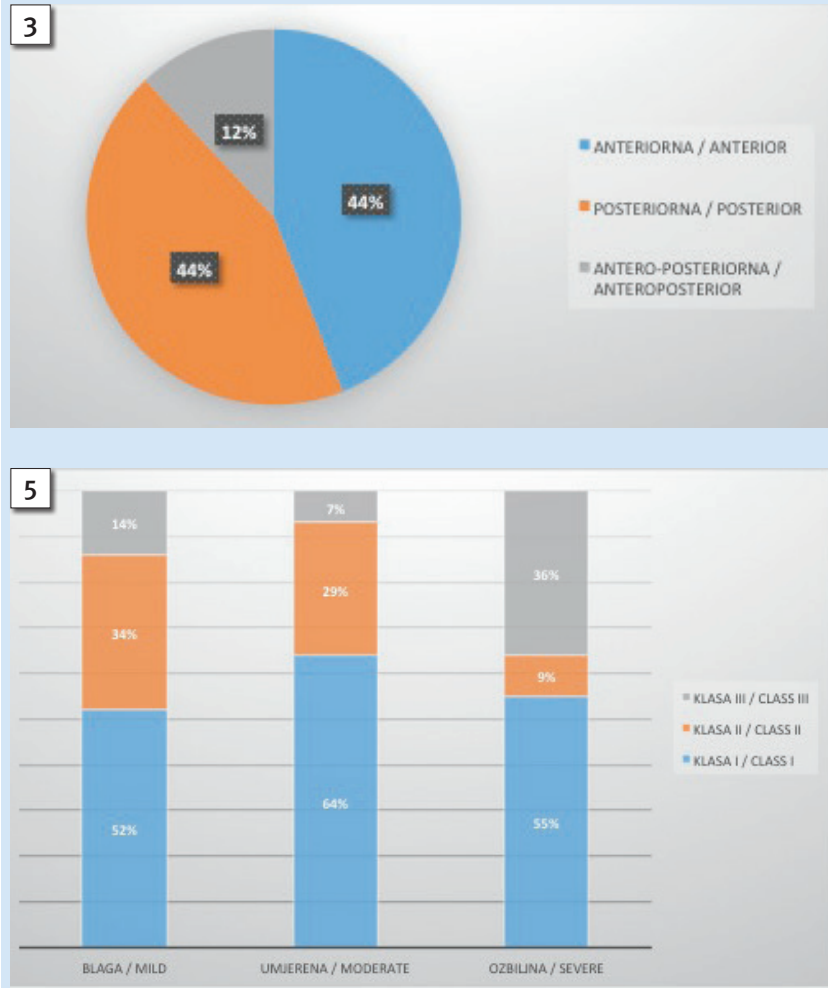

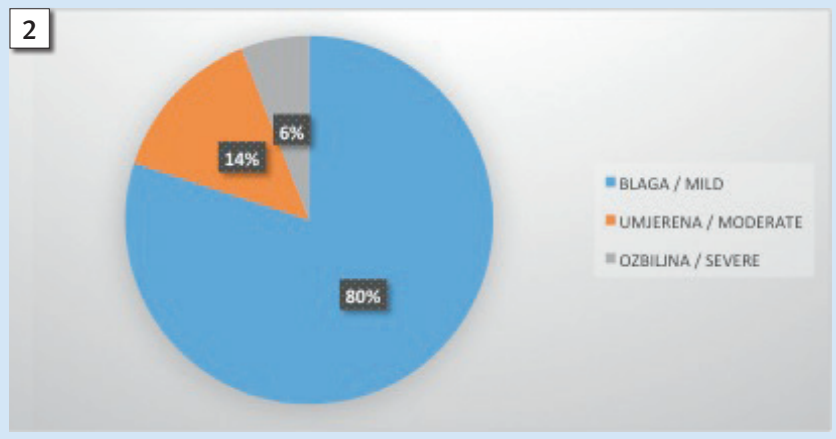

4

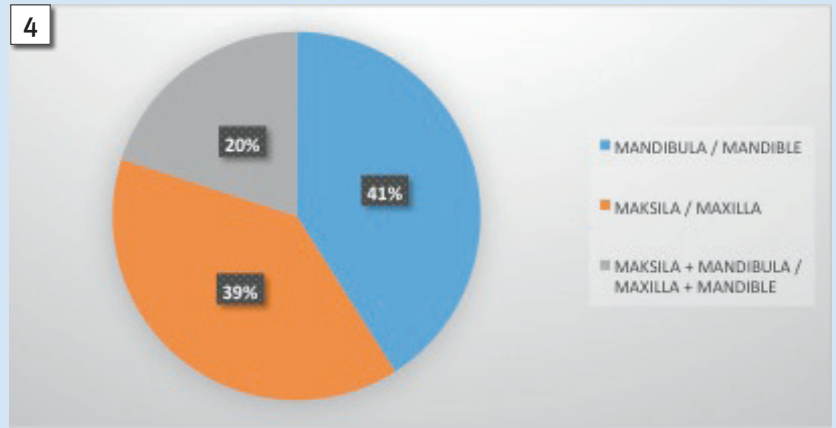

6

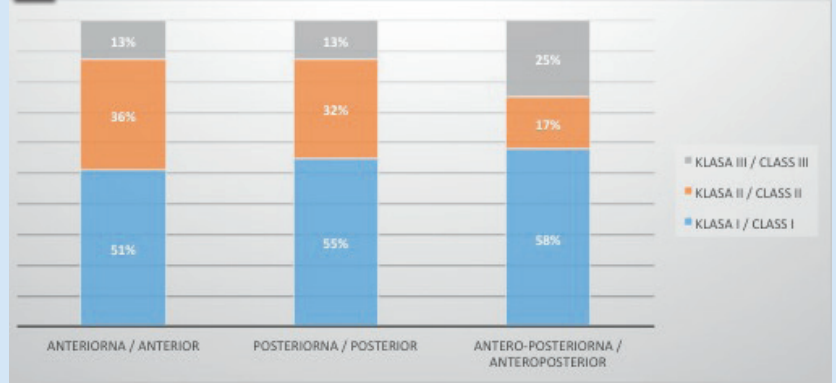

Figure 1 Frequency histogram for number of persons by number of missing teeth

Slika 1. Histogram frekvencija za broj osoba prema broju zuba koji nedostaju

Figure 2 Severity of hypodontia

Slika 2. Opsežnost hipodoncije

Figure 3 Location of hypodontia in dental arch

Slika 3. Lokalizacija hipodoncije po segmentima čeljusti

Figure 4 Jaw localization of hypodontia

Slika 4. Lokalizacija hipodoncije prema lokalizaciji u čeljusti

Figure 5 Distribution of hypodontia by severity and skeletal class

Slika 5. Raspodijeljenost hipodoncije prema opsežnosti i skeletnim klasama

Figure 6 Distribution of hypodontia by location in dental arch and skeletal class

Slika 6. Raspodijeljenost hipodoncije prema antero-posteriornoj lokalizaciji i skeletnim klasama 
number of agenetic teeth (27). A tendency towards horizontal growth pattern in subjects with posterior hypodontia was reported by Bauer et al. (28). Another study published by Kreczi et al. (29) reported that in subjects with hypodontia neither a vertical nor a horizontal growth pattern is dominant.

\section{Conclusion}

Permanent dentition hypodontia among Croatian orthodontic patients was found to be generally mild, localized equally in the anterior and posterior segments in both the maxilla and the mandible. The number of missing teeth per person ranged from 1 to 12 , with no difference between genders.

The severity and location of hypodontia did not differ significantly between the genders, as well as in between the categories of vertical and sagittal skeletal growth pattern.

The obtained results suggest that the treatment plan for patients with hypodontia in permanent dentition should be individualized and adjusted for each case.

\section{Conflict of interest}

None declared su Bauer i suradnici (28). U istraživanju Kreczija i suradnika (29) zaključeno je da ni horizontalni, ni vertikalni obrazac rasta ne dominiraju u ispitanika s hipodoncijom.

\section{Zaključak}

Hipodoncija u trajnoj denticiji među hrvatskim pacijentima uglavnom je blaga, jednako lokalizirana u prednjim i stražnjim segmentima maksile i mandibule. Broj zuba koji nedostaju kretao se u rasponu od 1 do 12 po osobi, bez razlika među spolovima.

Opsežnost i lokalizacija hipodoncije nisu se značajno razlikovale među spolovima, ni među kategorijama sagitalnih i vertikalnih skeletnih obrazaca rasta.

Dobiveni rezultati pokazuju da pacijenti s hipodoncijom u trajnoj denticiji zahtijevaju individualizirani pristup pri izradi plana terapije.

\section{Sukob interesa}

Nije ga bilo.
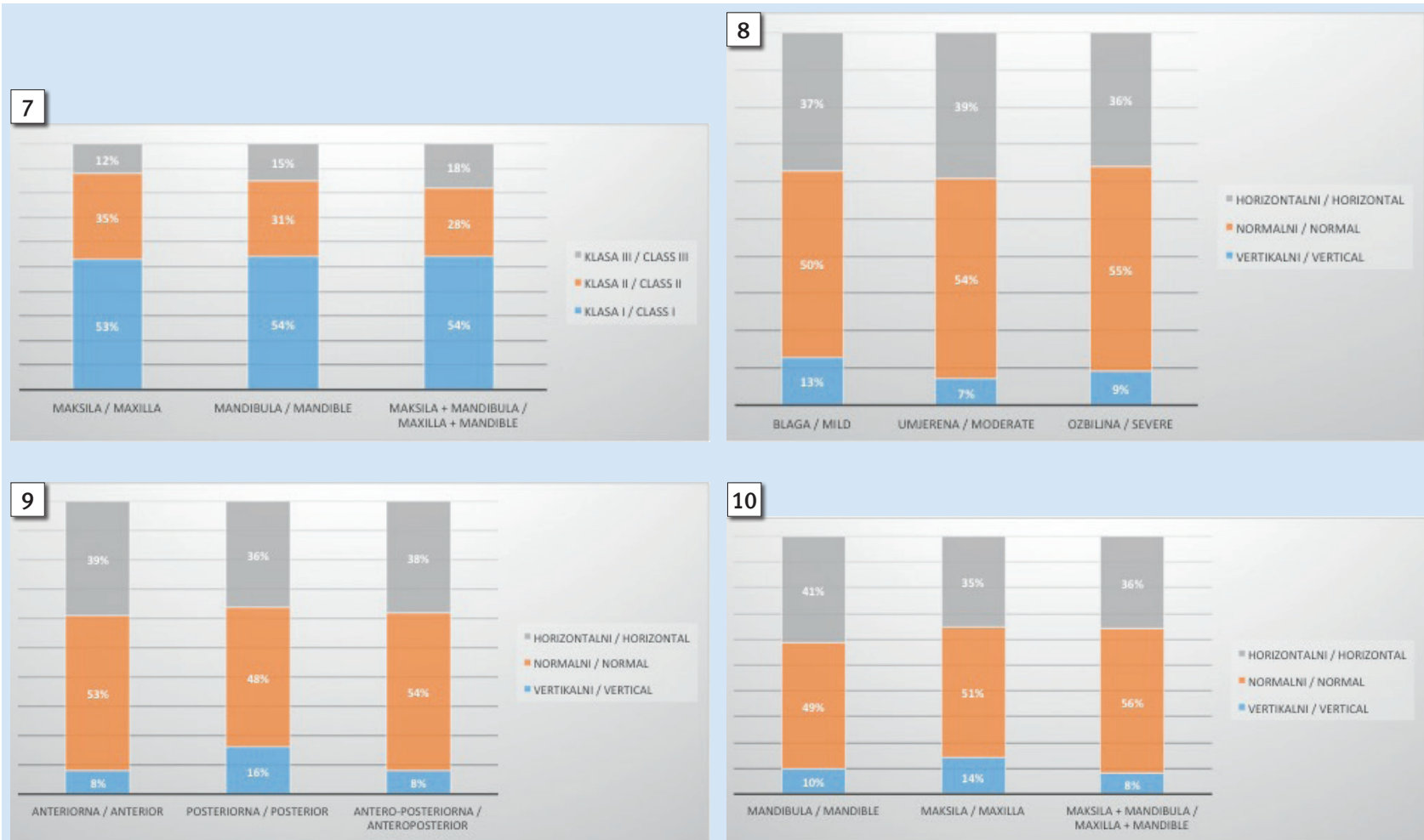

10

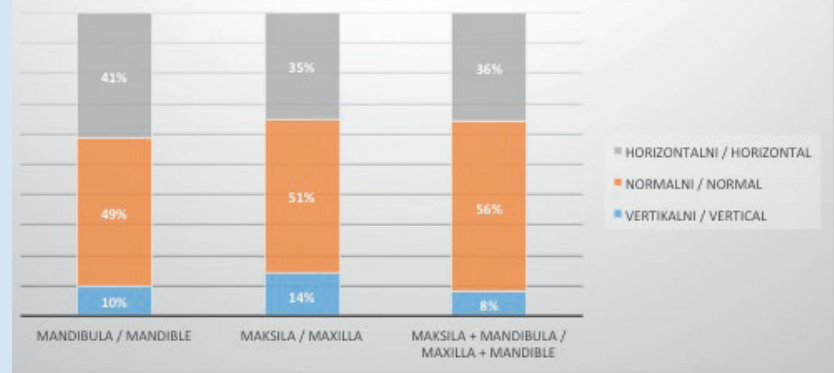

Figure 7 Distribution of hypodontia by jaw localization and skeletal class

Slika 7. Raspodijeljenost hipodoncije prema lokalizaciji u čeljusti i skeletnim klasama

Figure 8 Distribution of hypodontia by severity and facial growth pattern

Slika 8. Raspodijeljenost hipodoncije prema opsežnosti i obrascu rotacijskoga rasta lica

Figure 9 Distribution of hypodontia by location in dental arch and facial growth pattern

Slika 9. Raspodijeljenost hipodoncije prema antero-posteriornoj lokalizaciji i obrascu rotacijskoga rasta lica

Figure 10 Distribution of hypodontia by jaw localization and facial growth pattern

Slika 10. Raspodijeljenost hipodoncije prema lokalizaciji u čeljusti i obrascu rotacijskog rasta lica 
Sažetak

Svrha: Ovim retrospektivnim istraživanjem željela se procijeniti učestalost hipodoncije u trajnoj den ticiji kod ortodontskih pacijenata u Republici Hrvatskoj. Pojavnost je procijenjena s obzirom na spol, specifične zube koji nedostaju, lokalizaciju u čeljusti i prema segmentima čeljusti te s obzirom na sagitalne i vertikalne skeletne obrasce rasta. Ispitanici i postupci: Uzorak se sastojao od 194 ispitanika (75 muškaraca i 119 žena) izdvojenih iz baze podataka pacijenata Zavoda za ortodonciju Klinike za stomatologiju Kliničkoga bolničkog centra Zagreb. Prema opsežnosti hipodoncije bili su podijeljeni u skupine s blagom hipodoncijom (nedostatak $1-2$ zuba), umjerenom (nedostatak $3-5$ zuba) te ozbiljnom (nedostatak 6 ili više zuba). Prema lokalizaciji hipodoncije prema segmentima čeljusti ispitanici su podijeljeni u skupine $s$ anteriornom (interkanina regija), posteriornom (regija premolara i molara) te antero-posteriornom hipodoncijom (kombinacija prvih dviju skupina). U obzir je također uzeta lokalizacija hipodoncije po čeljustima. Rezultati: Hrvatski pacijenti s hipodoncijom u trajnoj denticiji uglavnom su imali blagu hipodonciju (80\%), podjednako zastupljenu u maksili (39\%) i mandibuli (41\%) te u prednjim i stražnjim segmentima čeljusti (44\%). Broj zuba koji nedostaju kretao se u rasponu od 1 do 12 po osobi i nije bilo razlike među spolovima. Opsežnost i lokalizacija hipodoncije nisu se značajno razlikovale među spolovima, kao ni među kategorijama sagitalnih i vertikalnih skeletnih obrazaca rasta. Zaključak: Dobiveni rezultati pokazuju da pacijenti s hipodoncijom u trajnoj denticiji zahtijevaju individualizirani pristup pri izradi plana terapije.
Zaprimljen: 13. travnja 2020. Prihvaćen: 1. lipnja 2020.

Adresa za dopisivanje

Daša Nikolov Borić

Dom zdravlja Zagreb - Centar

Runjaninova 4, Zagreb

nikolov_dasha@hotmail.com

Ključne riječi

anodoncija; trajna denticija; rotacijski obrazac; Hrvatska

\section{References}

1. Goodman JR, Jones SP, Hobkirk JA, King PA. Hypodontia: 1. Clini cal features and the management of mild to moderate hypodontia. Dent Update 1994;21:381-4.

2. Khalaf K, Miskelly J, VogeE, Macfarlane TV. Prevalence of hy podontia and associated factors: a systemic reviewand metaanalysis. J Orthod. 2014 Dec;41(4):299-316.

3. Matalova E, Fleischmannova J, Sharpe PT, Tucker AS. Tooth agenesis: from molecular genetics to molecular dentistry. J Dent Res. 2008 Jul;87(7):617-23.

4. Polder BJ, Van't Hof MA, Van Der Linden FPGM, Kuijpers-Jagtman AM. A meta-analysis of the prevalence of dental agenesis of permanent teeth. Community Dent Oral Epidemiol. 2004 Jun;32(3):217-26

5. Endo T, Ozoe R, Kubota M, Akyiama M, Shimooka S. A survey of hypodontia in Japanese orthodontic patients. Am J Orthod Dentofacial Orthop. 2006 Jan;129(1):29-35.

6. Sisman Y, Uysal T, Gelgor IE. Hypodontia. Does the prevalence and distribution pattern differ in orthodontic patients? Eur J Dent. 2007 Jul;1(3):167-73

7. Reshitaj A, Krasniqi D, Reshitaj K, Anic-Milosevic S. Hypodontia, gender-based differences and its correlation with other dental clinical features in Kosovar adolescents. Acta Stomatol Croat. 2019;53(3):347-53.

8. Rakhshan V. Congenitally missing teeth (hypodontia): A review of the literature concerning the etiology, prevalence, risk factors, patterns and treatment. Dent Res J (Isfahan). 2015 JanFeb;12(1):1-13.

9. Silva Meza R. Radiographic assessment of congenitally missing teeth in orthodontic patients. Int J Pediatr Dent. 2003;13(2):112-6.

10. Amini F, Rakhshan V, Babaei P. Prevalence and pattern of hy podontia in the permanent dentition of 3374 Iranian orthodontic patients. Dent Res J (Isfahan). 2012 May;9(3):245-50.

11. Nunn JH, Carter NE, Gillgrass TJ, Hobson RS, Jepson NJ, Meechan JG, et al. The interdisciplinary management of hypodontia: Background and role of paediatric dentistry. Br Dent J. 2003 Mar $8 ; 194(5): 245-51$

12. Fekonja A. Hypodontia in orthodontically treated children. Eur J Orthod. 2005 Oct;27(5):457-60.

13. Celikoglu M, Kazanci F, Miloglu O, Oztek O, Kamak H, Ceylan I. Frequency and characteristics of tooth agenesis among an orthodontic patient population. Med Oral Patol Oral Cir Bucal. 2010 Sep 1;15(5):e797-801.

14. Aktan A, Kara I, Şener İ, Bereket C, Ay S, Çiftçi M. Radiographic study of tooth agenesis in the Turkish population. Oral Radiol. 2010;26(2):95-100.

15. Chung $\mathrm{CJ}$, Han JH, Kim $\mathrm{KH}$. The pattern and prevalence of hypodontia in Koreans. Oral Dis. 2008 Oct;14(7):620-5.

16. Wisth PJ, Thunold K, Böe OE. The craniofacial morphology of indi viduals with hypodontia. Acta Odontol Scand. 1974;32(4):281-90.

17. Badrov J, Gašpar G, Tadin A, Galić T, Kalibović Govorko D, Gavić L, et al. Prevalence and characteristics of congenitally missing permanent teeth among orthodontic patients in southern Croatia. Acta Stomatol Croat. 2017;51(4):290-9.

18. Bäckman B, Wahlin YB. Variations in number and morphology of permanent teeth in 7-year-old Swedish children. Int J Paediatr Dent. 2001 Jan;11(1):11-7.

19. Kim YH. Investigation of hypodontia as clinically related den- tal anomaly: Prevalence and characteristics. ISRN Dent. 2011;2011:246135.

20. Dolder E. Deficient dentition. Dent Pract Dent Rec. 1936;57:142-3.

21. Silverman NE, Ackerman JL. Oligodontia: A study of its prevalence and variation in 4032 children. ASDC J Dent Child. 1979 NovDec;46(6):470-7.

22. Endo T, Ozoe R, Yoshino S, Shimooka S. Hypodontia patterns and variations in craniofacial morphology in Japanese orthodontic patients. Angle Orthod. 2006 Nov;76(6):996-1003.

23. Vahid-Dastjerdi E, Borzabadi-Farahani A, Mahdian M, Amini N. Non-syndromic hypodontia in an Iranian orthodontic population. J Oral Sci. 2010 Sep;52(3):455-61.

24. Chung LK, Hobson RS, Nunn JH, Gordon PH, Carter NE. An analysis of the skeletal relationships in a group of young people with hypodontia. J Orthod. $2000 \mathrm{Dec} ; 27(4): 315-8$.

25. Acharya PN, Jones SP, Moles D, Gill D, Hunt NP. A cephalometric study to investigate the skeletal relationships in patients with increasing severity of hypodontia. Angle Orthod. 2010 Jul;80(4):511-8.

26. Hirukawa K, Iwata R, Kurosawa M, Kondo T, Goto S. Statistical investigation about the prevalence of congenitally missing perma nent teeth. Orthod Waves. 1999;58:49-56.

27. Øgaard B, Krogstad O. Craniofacial structure and soft tissue profile in patients with servere hypodontia. Am J Orthod Dentofacial Orthop. 1995 Nov;108(5):472-7.

28. Bauer N, Heckmann K, Sand A, Lisson JA: Craniofacial growth pat terns in patients with congenitally missing permanent teeth. J Orofac Orthop. 2009 Mar;70(2):139-51.

29. Kreczi A, Proff P, Reicheneder C, Faltermeier A. Effects of hypodontia on craniofacial structures and mandibular growth pattern. Head Face Med. 2011 Dec 6;7:23.

30. Miličić A, Čanak V. Hypodontia and accompanying phenomena. Acta Stomatol Croat. 1975;9:133-40.Viskovic R, Jursic A, Cmelnik N. Hypodontia--prevalence and variations in orthodontic patients. Acta Stomatol Croat. 1988;22(1):23-30.

31. Viskovic R, Jursic A, Cmelnik N. Hypodontia - prevalence and variations in orthodontic patients. Acta Stomatol Croat. 1988;22(1):23-30.

32. Gomes RR, da Fonseca JA, Paula LM, Faber J, Acevedo AC. Prevalence of hypodontia in orthodontic patients in Brasilia, Brazil. Eur J Orthod. 2010 Jun;32(3):302-6.

33. Behr M, Proff P, Leitzmann M, Pretzel M, Handel G, Schmalz G, et al. Survey of congenitally missing teeth in orthodontic patients in Eastern Bavaria. Eur J Orthod. 2011 Feb;33(1):32-6.

34. Galluccio G, Pilotto A Genetics of dental agenesis: Anterior and posterior area of the arch. Eur Arch Paediatr Dent. 2008 Mar;9(1):41-5.

35. Thompson GW, Popovich F. Probability of congenitally missing teeth: Results in 1,191 children in the Burlington Growth centre in Toronto. Community Dent Oral Epidemiol. 1974;2(1):26-32.

36. Peker I, Kaya E, Darendeliler-Yaman S. Clinic and radiographical evaluation of non-syndromic hypodontia and hyperdontia in permanent dentition. Med Oral Patol Oral Cir Bucal. 2009 Aug 1;14(8):e393-7.

37. Tallón-Walton V, Nieminen P, Arte S, Carvalho-Lobato P, UstrellTorrent JM, Manzanares-Céspedes MC. An epidemiological study of dental agenesis in a primary health area in Spain: Estimated prevalence and associated factors. Med Oral Patol Oral Cir Bucal. 2010 Jul 1;15(4):e569-74. 